\section{DIGITAL COMMONS \\ @ UNIVERSITY OF SOUTH FLORIDA}

\section{ABO: Interactive Journal for Women in the Arts, 1640-1830}

Volume 2

Issue 1 Volume 2.1 (Spring 2012): Open Access

Article 2

2012

\title{
Fatally Enjoy'd: Rape, Resilience, and the Accessibility in Aphra Behn's The Dumb Virgin
}

\author{
Emily Bowles \\ University of Wisconsin-Fox Valley, emily.bowles@uwc.edu
}

Follow this and additional works at: https://digitalcommons.usf.edu/abo

Part of the Dramatic Literature, Criticism and Theory Commons, Educational Methods Commons, Feminist, Gender, and Sexuality Studies Commons, and the Literature in English, British Isles Commons

\section{Recommended Citation}

Bowles, Emily (2012) "Fatally Enjoy'd: Rape, Resilience, and the Accessibility in Aphra Behn's The Dumb Virgin," ABO: Interactive Journal for Women in the Arts, 1640-1830: Vol.2: Iss.1, Article 2.

http://dx.doi.org/10.5038/2157-7129.2.1.1

Available at: https://digitalcommons.usf.edu/abo/vol2/iss1/2

This Scholarship is brought to you for free and open access by Digital Commons @ University of South Florida. It has been accepted for inclusion in ABO: Interactive Journal for Women in the Arts, 1640-1830 by an authorized administrator of Digital Commons @ University of South Florida. For more information, please contact digitalcommons@usf.edu. 
Fatally Enjoy'd: Rape, Resilience, and the Accessibility in Aphra Behn's The Dumb Virgin

\author{
Keywords \\ access, Aphra Behn, disability, rape, The Dumb Virgin \\ Creative Commons License \\ (c) $($ i) $\Theta$
}

This work is licensed under a Creative Commons Attribution-No Derivative Works 3.0 License. 
She held out against all his Assaults above two Hours, and often endeavoured to Struggle from him, but durst make no great Disturbance, thro' fear of Alarming the Company below.

As an employee of a Sexual Assault Service Provider (SASP), I have read police reports that express the same sense of silent struggle communicated by Aphra Behn's narrator in her description of a mute woman's fight against her overzealous lover's sexual advances. This passage, from Behn's posthumously published narrative The Dumb Virgin: Or, The Force of Imagination (1700), shows how little has changed in social perceptions of female agency and consent, especially when marginal sexualities and intersectional forms of oppression are overlaid on a heterosexual, erotic relationship.

In this crucial textual moment, Behn shows a woman whose fear of "Alarming the Company below" overshadows her desire to protect her own bodily integrity. What is not immediately obvious, though, is that the woman described in this passage literally cannot speak: she was born mute, and her struggle to give voice to her bodily needs and desires is one of the main themes of the text. Throughout The Dumb Virgin, Behn literalizes a metaphor of female voicelessness and non-agency. One of her two protagonists cannot speak, which simultaneously allows Behn to render her as an extreme or exaggerated variation on the apotheosis of subservient womanhood while using the character to demonstrate the explicit dangers of female silence.

The Dumb Virgin tells the story of two sisters and a brother whose defects, both in body and fate, are engendered by their mother's failure to conform to the correct paradigm for maternal behavior. Although the mother figures only briefly in the text and is not even given a name, Behn represents her as the instigator of her daughters' physical disabilities, her son's accidental incestuous rape of one of the daughters, and the rest of the text's tragic unfolding. The mother first exhibits a decidedly unfeminine, amorous urge to travel. Her passions distort and twist the limbs of her daughter Belvideera, and her extreme sadness after the supposed loss of her son leads her younger daughter to be flawlessly beautiful but mute.

The heroines' bodies—one of which is distorted and bent, the other, physically perfect yet "naturally and unfortunately Dumb" - embody the always unstable relationship between beauty and monstrosity that becomes, in this text, a practical grid of sorts for determining the relative accessibility of female bodies to masculine power. Disability interacts with gender and class in ways that produce marked versions of femininity. As Emily Cockayne notes in a study of deafness during the early modern period, "The opportunities for the aristocratic prelingually deaf seemed to be little hampered by their disability" (509), meaning that class cuts across lines of gender and ability. In a broader study of disability, historian Ingunn Moser has suggested that, at times, an event or interaction renders disability irrelevant "while gender is made relevant" (538). Both the historically specific idea that disability interacts with seventeenth-century assumptions about privilege and power, as well as the enduring ways in which desire can momentarily displace other values, determine the meaning and worth of disabled women's bodies in The Dumb Virgin.

Behn's narrative represents disability as an always shifting value that depends on her female characters' other methods of gendered embodiment. The daughters in The Dumb Virgin grow 
into what seems an extension of the dichotomy they uphold at birth: the deformed and brilliant daughter situated always in opposition to the beautiful yet silent sister. Behn introduces an unexpected twist, though, by suggesting that both women ably learn the codes of amatory discourse as the same man finds himself entranced by both of them. Dangerfield rapes Maria; it is then revealed to him that Maria is his sister. She cries out, speaking her only words before impaling herself on his dagger. The father and Dangerfield die as well, leaving "the surviving Sister most miserable, because she must survive such misfortunes” (359). In this final narrative moment, the audience is left entirely without a sign of so-called normal femininity and therefore without an index for determining value.

Behn authenticates the story of The Dumb Virgin by entering into the text through a first-person narrator, who states, "I lodged within three doors of Rinaldo's House, and running presently thither, saw a more bloody tragedy in reality, than what the most moving scene ever presented" (359). As in other narratives in which Behn utilizes a female narrator, The Dumb Virgin represents female sexual agency as the product of multiple voices. The female narrator provides her readers with an immediate interpretation of the surfaces of her characters' bodies while enmeshing her own body in the same discourses of desire and legibility. ${ }^{1}$

As in Love-Letters between a Nobleman and His Sister (1684-87), The Fair Jilt (1688), Oroonoko (1688), The Lucky Mistake (1689), The History of the Nun (1689), The Nun (1697), The Unfortunate Bride (1700), and The Unfortunate Happy Lady (1700), Behn introduces a female narrator who functions as the authorial "I" of the text. The female narrator in these texts often possesses an ability to critique female sexual marginalization while offering some degree of sympathy for women who are attempting, in some way, to establish sexual autonomy.

For example, in The Fair Jilt, Miranda falsely accuses a priest of raping her when he fails to respond to her seduction attempts. Throughout the text, Miranda's actions are scrutinized by an unforgiving culture, yet the hero and the narrator ultimately enfold her in language that allows her to have sexual prerogatives far beyond those accorded to most women. I view Behn's first representation of Miranda, in which she calls her "my Fair Jilt" and supplies her with a "feign'd name” (9) as an act of protection. She wants her reader to see a relationship between the narrator and Miranda that is almost conspiratorial, and in the penultimate paragraph of the text, she withdraws, using third person information to develop distance between the narrator and Miranda: "They say Miranda has been very penitent for her life past, and gives Heaven the Glory for having given her these Afflictions, that have reclaim'd her . . ” (48). The narrator never overtly describes Miranda's past as requiring penitence or her new trajectory as being somehow better than her sexually adventurous desire for power. Similarly in The Unfortunate Bride, female characters implicate one another in sexual transgressions, while the narrator aligns herself with the anti-heroine, a narrative act that communicates Behn's awareness of the complex negotiations women make as they attempt to acquire sexual autonomy.

The Dumb Virgin and The Unfortunate Bride are notable in that, in these texts, Behn explicitly ties female sexual autonomy to physical disability or defect. Behn crafts these narratives to amplify the corporeal practices that create femininity and thus draw attention to the ways in which femininity and femaleness are always already marked as defective. Behn rarely uses the 
words defect and deformity in her narrative, even though these terms were available to and meaningful for seventeenth-century authors. She most frequently draws on these words in an aesthetic context, as in the dedication of Oroonoko, in which she states, "if there be a Scar, an ungrateful Mole, or any little Defect, they leave it out; and yet make the Picture extreamly like: But he who has the good Fortune to draw a Face that is exactly Charming in all its Parts and Features, what Colours or Agreements can be added to make it Finer?” (54). The language of defect here is entirely stylized, connected as it is to mimetic sensibilities rather than a real or essential physical form. This rhetorical maneuver becomes a way of linking authorship to maternity. While the mother is implicated in creating defect by medical models, the author is given the inverse power of omission, for she is able to selectively represent her characters. Behn understands that the author chooses which features to make visible to readers.

In The Dumb Virgin, as was typical in Restoration and eighteenth-century literature, the disabled female body bears the marks of cultural meanings that are, effectively, only intelligible in so far as they are contextualized. The correct interpretation of body signs is always contingent; we read bodies through the cultural apparatuses that transform such features as skin color, moles, blemishes, and skeletal formation into signifiers of external and even internal value or merit. In addition to the corporeal signs read by-and, circularly, created by-medical discourse, the female body is overwritten by the language of a social and legal system that denies women personhood or recourse. Female consent is in some ways always implied and even required. Yet Behn's narratives highlight the stories of women who refuse to consent to some form of sexual subjugation. These texts also highlight instances in which consent to sexual acts becomes the ultimate act of disempowerment, a submission as much to boundaries as to desires. Her texts suggest that sexuality is always in circulation and that consent is sometimes precluded because of the social misalignment of corporeal gestures and voice. Amatory bodies are not expected to say no. Many of Behn's heroines literally cannot say no. Neither can men, if they possess feminine traits or have internalized a sense of abjection.

Behn was writing at a crucial moment, when rape was being re-encoded not as a crime of property but as a crime against women, and her representations help shed light on the ways in which these sexual, political, and legal shifts were not easy ones. In the same way, she was writing of disability and defect as these categories were being codified as essential flaws, linked to women's bodies in medical discourse. Medical texts represented the female body as something with corporeal meaning and power that needed to be chastened, perhaps as a way of controlling female sexuality as women acquired slightly more sexual autonomy.

Medical texts based on Galenic and Aristotelian traditions imagined women as possessing bodies that bordered on monstrous. In these discourses, the female form is always designated as abject, other, and incomplete; the naturalization of this belief in female defectiveness legitimizes sociocultural privileging of the masculine body and of broader patriarchal values.

Scientific discussions of disability or difference very seamlessly shifted from descriptive to prescriptive. Aristotle's Master-Piece Compleated (not written by Aristotle but rather signed by William Salmon) relentlessly assigns values to women's bodies in such a way as to create a medical tradition that supported and sustained misogynistic values. In this text, like so many 
other medical guides published during the late seventeenth and early eighteenth century, disabilities are imagined as the embodiment of social transgressions, often of both class and gender.

Within this intellectual culture, it is not surprising that female midwives like seventeenth-century Jane Sharp participated in the process of blaming women for creating defects while codifying women's bodies as lesser or lacking. In The Midwives Book (1671), Sharp notes, "It was the judgment of Hippocrates, that women's wombs are the cause of all their diseases” (129). Behn inserts these ideas into The Dumb Virgin by representing Belvideera and Maria's mother's womb as the source of the daughters' disabilities, but she also challenges any simplistic rendering of the biological production of difference throughout the text by refusing to align the resulting disabilities with a lack of beauty, sexuality, or agency.

The medical creation of disability as a gendered trait extended from and compounded the ongoing attempt by philosophers and medical writers to create "the ugly, the deformed, and the helpless" as reminders of power through its opposite (Kudlick 560). As Catherine J. Kudlick has noted, disability has persistently been linked to gender in efforts to marginalize women and consolidate masculine power. From the sixteenth century onward, Kudlick argues, "disability, femininity, and powerlessness" were conflated to preserve social order (560). ${ }^{2}$

In these trajectories, femininity manifests in so inherently defective a fashion that the female body breaks down against the pressures of masculine desires, especially when it is inscribed with the complex bric-a-brac of intersectional attributes such as race and ability that throw gender difference into relief. Historicized accounts of the ways in which deformity is aligned with womanhood as a marker of difference but also a marker of virtue render woman (in Rosi Braidotti's words) as "a sign of difference” that is "monstrous" (65). The linking of deformity, disability, femaleness, difference, and even monstrosity results in a false naturalization of binary oppositions based on both male versus female and able versus disable. This system of value plays a significant role in how restoration and eighteenth-century authors conferred value on bodies in their works and also in these authors' comic or tragic opening up of bodies. As Allison P. Hobgood and David Houston Wood have noticed, early modern discourses of "the able body constructed the disabled body as its oppositional term," an interpretation that Felicity Nussbaum shares: "the various kinds of difference interrelate to complicate prevailing ideas about the cultural meanings of normalcy. ..." (1).

Disability is not, for Behn, however aligned with monstrosity. She writes with an awareness of medical, political, and sexual alignments between deformity and gender or sexuality set up by writers including Michel de Montaigne and Frances Bacon, who elaborate two distinct and representative positions: Montaigne identifies deformity as reflective of internal defects, and Bacon views disabilities as productive of behaviors. ${ }^{3}$ But the women in The Dumb Virgin are never presented as caricatures, and neither woman can be reduced to the typical devaluation of voicelessness or deformity.

By the mid-eighteenth century, William Hay’s Deformity: An Essay (1754) would set up disability as a sort of secret history. In his words, "Bodily Deformity is visible to every eye; but the Effects ... are known to very few; intimately known to none but those who feel them; and 
they generally are not inclined to reveal them” (A3). This binary between what is externally visible and internally felt circulates in Behn's writing because, like Eliza Haywood and Delarivier Manley after her, she represents her writing as secret histories or scandal narratives that expose the private stories behind public events. But we can expand this idea further as the story of the female body in general and the sexual female body in particular during the seventeenth and eighteenth centuries was always designated as private and even unspeakable.

$* * *$

The unspeakable story is, for Behn, one that must be told. She uses The Dumb Virgin to respond to social configurations of femininity as a form of defect by imagining two women who literally embody the weakness seventeenth-century science accords to them. When they are imprinted on the body and the senses, disability and marks of cultural difference simultaneously render women more and less accessible to male sexual prerogatives.

The plot of The Dumb Virgin begins with a mother's failure to conform to gendered expectations and unfolds to highlight the effects of the mother's transgressions on her children's bodies. Rinaldo's wife, a woman so marginalized by codes of gender and class that she does not even have a name, makes choices that are textually imagined to create bodies that exist beyond the spectrum of perceived normalcy. After giving birth to a son, she entreats her husband to let her visit an exotic island. She travels with her son and a servant. Before reaching the island, the ship is intercepted by pirates. Rinaldo's wife endures loss of liberty, separation from her husband, and loss of her child, who escapes with a trusted servant but is presumed dead. She responds with a "typical” feminine weakness of mind (343), which remains a shaping force after she is restored to Venice. She becomes pregnant, but the child she produces pathologically reiterates the structure of her trauma: “'twas a Daughter, its Limbs were distorted, its Back bent, and tho' the face was the freest from Deformity, yet had it no Beauty to Recompense the Dis-symetry of the other Parts” (344). The child lacks symmetry, which early modern writing always links withand views as essential to-beauty because of what Sharp calls the "sympathy between the womb and other parts” (126). Behn inserts this medical understanding in her text, but she also challenges the discourse by showing profound and unacknowledged interpenetrations among childbirth and maternal psychology.

Following Belvideera’s birth, “the Mother grew very Melancholy, rarely speaking, and not to be comforted by any Diversion” (344). Her silence then leads her to give birth to "the most beautiful Daughter to the World that ever adorn'd Venice, but naturally and unfortunately Dumb, which defect the learn'd attributed to the Silence and Melancholy of the Mother, as the Deformity of the other was to the Extravagance of her Frights" (344). That "agreement between the womb and Brain” that Sharp locates as so critical to fetal development leads to the birth of a mute child. Women "lived in a culture... in which their pregnancies became the ecosystem which determined their future child's health," which led to "perceptions of pregnancy ... [that] control women’s bodies and undermine women’s autonomy” (Sharp 126; Gowing 122).

The mother is effectively blamed in the text for her "Silence and Melancholy" as well as for the "Extravagance of her frights," and the father takes on the role of postnatal parenting. He "directs his thoughts to the care of his Children, their defects not lessening his inclination, but stirring up his endeavours in supplying the defaults of Nature by the industry of Art” (344). The care 
Rinaldo takes in his daughters' "breeding and education" cannot transform their bodies or senses, but it ensures that their defects are coupled with skills that make them prodigies. Rinaldo privileges art over nature; he creates his children's identities a second time so that both women become manifestations of entirely corporeal and entirely intellectual effects. He literally imagines his daughters' bodies into an alternative system of value and meaning, and he inscribes each of them with a form of intelligibility that is culturally valued even in so far as it is disconnected from or at odds with his daughters' gender. He facilitates Belvideera's studiousness and trains Maria in the emergent technique of sign language.

As Behn develops the sisters' characters, she highlights their differences but also identifies both of them as possessing traits that make them exemplary among women. The narrator privileges these women for their differences and suggests that their disabilities provide them with meaning and value far beyond those accorded to most women within the contours of seventeenth-century sociosexual values.

For both sisters, this exceptionalness is something that the narrator understands in a way that others do not. Of Belvideera, the narrator notes:

by the sixteenth Year of her Age, she understood all the European Languages, and cou'd speak most of 'em, but was particularly pleas'd with the English, which gave me the Happiness of many Hours Conversation with her; and I may ingenuously declare, 'twas the most Pleasant I ever enjoy'd, for besides a piercing Wit, and depth of Understanding peculiar to herself, she delivered her Sentiments with that easiness and grace of Speech, that it charm'd all her Hearers. (344-45)

She has a voice that is annexed to great intelligence, and Behn's narrator takes on a function not only of describing this intelligence but also of partaking in it. Similarly, Maria's beauty is so great that "the most famous Painter in Italy" is so disarmed by it that "he let his Pencil drop and spoiled the Picture" (345). When he continues to fail, "the Lady vexed at the weakness of the Painter, took up his Pencils and the Picture, and sitting down to her glass finished it herself” (345). Behn's narrator takes up where the painter fails by representing Maria's beauty in her prose.

Her writing preserves Belvideera’s intelligence and Maria’s body in a hierarchy that underscores but subtly dismantles social conventions. Belvideera's disfigured body does not negate her corporeal desires or make her identity hinge on her intelligence, and Maria's beautiful but mute body does not render her incapable of communicating through art, signs, and alternate modes of discourse. Behn recognizes that, although the women she describes are largely identified by the disabilities that amplify and extend their feminine dependence on their father and his protections, neither Belvideera nor Maria is reducible to the signs of difference written on their bodies.

Specifically, at several points in the text, Behn interrogates the correspondence between defect and femininity and ultimately shows that such overreliance on others' correct interpretation of corporeal legibility leads to abuses of power. Maria's use of sign language could have served as a viable alternative to an overreliance on the amatory meanings provided by her body and its beauty. Sign languages for the deaf gained popularity and public accessibility during the 
seventeenth century through texts including John Bulwer's Chirologia: Or the Natural Language of the Hand (1644); however, Cockayne notes, "As employment of sign language was infrequently recorded, it is difficult to judge the prevalence of its use” (503). Cockayne cites several late seventeenth and early eighteenth-century records detailing the communicativeness of the prelingually deaf. ${ }^{4}$ William Holder's 1669 essay Elements of Speech and one of Richard Steele's later Spectator essays both depict deaf mute individuals as utilizing their eyes, their countenances, and their gestures to communicate.

Descriptions of the prelingually deaf using gestures to communicate ultimately reflect a dangerous and reductive tendency that Behn suggests binds those who are voiceless in the words others want them to say. Maria's extreme beauty, coupled with her silence, makes her a site of perpetual inscription. Her beauty is so great that "the Language of her Eyes sufficiently paid the Loss of her Tongue, and there was something so Commanding in her Look, that it struck every Beholder as dumb as herself" (345). Within the context of amatory fiction, the erotic legibility of her body equalizes her with many heroines, for women in such texts rarely communicate with the men who view and consume their bodies through sighs, tears, smiles, and other gestures.

Belvideera is the only person who communicates with Maria in a language she can share, which produces a bond of intelligibility between them that is ultimately destroyed when both women realize they want to participate in the network of sexual exchange that reduces both of them to their beauty and thus to their bodies. With her sister, Maria perfects "silent Conversation with her Sister so far, that she was understood by her, as if she had spoke, and I remember this Lady was the first I saw use the significative Way of Discourse by the Fingers; I dare not say 'twas she invented it (tho' it probably might have been an Invention of these ingenious Sisters) but I am positive none before her ever brought it to that Perfection” (345). Behn sets up an intentionally confusing duality here. She suggests that beautiful women do not need to speak with any language other than the sighs, tears, and language of the eyes so typical of amatory fiction while acknowledging that, for a disabled woman, lacking a real voice requires a complicated and disciplined approach to learning an alternative sign system.

Both women's preference for alternate semantic systems over amatory discourse leads them to lack intelligibility and interpretative ability, even though the skills their father confers on them seem at first glance to set them up as superior communicators. The voices their father gives them do not correct the defects created by their mother's failings; rather, their learned modes of communication render them uniquely vulnerable, and the absence of their mother, who died giving birth to Maria, perhaps presents them with a gap in the education they should have received in how to correctly display and interpret the language of amatory discourse. Their defects make them fair but also reduce them to extremes of femininity that cannot exist within the contours of "correct" or able-bodied sexuality.

Belvideera and Maria are presented as two parts that together make a whole. Dangerfield tells Belvideera, "if you have the beauty of that Lady, or if she has your wit, I am the most happy, or the most unfortunate man alive” (347). Still, as Susanna B. Mintz’s insightful study of nonstandard bodies in Behn's writing indicates, Behn never adheres to simple formulations when she represents disability. One sister cannot complete the other, and although both in some ways serve as embodiments of social fetishizations of extremes, neither is simply an exaggerated 
version of so-called normal femininity. Rather, Maria’s body foregrounds the extreme preference for female docility and silence. Men view her beauty and interpret it according to their desires and the conventions of amatory fiction, and they read her silence as acquiescence, deferral, and tractability. This process replicates the concept that Susan Bordo has elegantly described, in which female desirability always falls onto a "continuum . . . [of] female disorder and 'normal' feminine practice" in which what is desirable is always already marked by difference and disorder (93). At the same time, the narrative highlights the ways in which such hyperfemininity precipitates its own failure.

Understood as an amatory body by Dangerfield and as a speaking subject by Belvideera, Maria becomes rendered as fragmented and incomplete. As they struggle to communicate with Dangerfield despite their own physical limitations (Belvideera's lack of beauty or symmetry and Maria's muteness), they begin to move away from the pragmatic tools their father gave them and toward a reliance on the corporeal conventions of amatory discourse. This break between the sisters is an extreme and even pathologized variation on the stereotypical catfights between women who fall in love with the same man. Belvideera attempts to stop the exchange and tries to tell Maria that she must not appear before anyone "because 'twere a shame to let Strangers know that you are dumb” (354), a comment that Maria refutes by gesturing at Belvideera's disfigured limbs. The sisters turn on one another in a striking example of female misogyny based on a mutual entrenchment in a system that devalues each of their bodies and, ultimately, relegates each of them to the periphery of sociosexual exchange.

When Dangerfield meets the sisters, The Dumb Virgin transforms from a story of defect engendered by a mother's faults (especially as those faults corresponded to medical discourses) into a narrative of elliptical eroticism, which in many ways typifies Behn's style of amatory fiction. Amatory discourse encircles the women, and ultimately the conventions of erotic exchange—-based as they are on the male gaze_-become the source of the women's meanings. Behn uses Maria's body to highlight how all female bodies are socially positioned in such a way that they cannot consent to erotic relationships: their desire and desirability are assumed and implicated. Behn thus allegorically works out a fundamental, gendered problem, and she does so in a way that showcases women's frustration with the illegibility they acquire because of the meanings wrongly attached to their bodies. The visible and material qualities of their bodies undermine their desire for sexual agency because they are misread. At the same time, these traits allow them moments of sexual liberty outside of the systems that render women docile and politically, socially, and sexually subservient.

When Dangerfield chooses Maria as the site and sign of his desires, it is largely because she has (in literary critic Ros Ballaster's words) "no control over [her body’s] messages” (87). He is captivated by Maria's "languishly soft" breasts. After learning that she is "naturally Dumb” (353), he is entirely seduced by her as she exists to him as an object of beautiful, eroticized, and voiceless femininity. Yet captivation, enslavement, and seduction are simply forms of male prerogative in the context of amatory discourse. Dangerfield has decided which woman he wants and how he wants her. The language of amatory discourse and the conventions of amatory fiction become the foundation upon which Behn's narrator can present a rape sequence that is confusingly based, in many ways, on the hero being overpowered by Maria’s beauty: 
She held out against all his Assaults above two Hours, and often endeavoured to Struggle from him, but durst make no great Disturbance, thro' fear of Alarming the Company below, at last he redoubling his Passion with Sighs, Tears, and all the rest of Love's Artillery, he at last gain'd the Fort, and the poor conquered Lady, all panting, soft, and trembling every Joynt, melted by his Embraces, he there fatally enjoy'd the greatest Extasy of Bliss, heightened by the Circumstances of Stealth, and Difficulty in obtaining. The ruin'd Lady now too late deplored the Loss of her Honour; but he endeavour'd to Comfort her by making Vows of Secrecy, and promising to salve her Reputation by a speedy Marriage, which he certainly intended, had not the unhappy Crisis of his Fate been so near. (444)

Maria’s meanings here are fragmented. She struggles but strives to "make no great Disturbance," subordinating her impulse to protect herself to a sense of social decorum. She fights but is "panting, soft, and trembling." For women, disabled or able-bodied, the sheer absence of state and social agency renders meaning making and consent always already fragmentary. Maria cannot consent, just as she cannot state her desire. In the sexual encounter, it is difficult to disentangle the disabled heroine from an able-bodied one. The mute woman momentarily has as much of a voice as a typical amatory heroine-or, conversely, the typical amatory heroine always only has as much of a "voice” as a mute woman does.

The voicelessness produced by Maria's mother's womb is also dismantled by it. Maria speaks when she learns that her lover, or her rapist, is her brother. She exclaims, "Oh! Incest, Incest" and commits suicide (444). After their deaths, Maria and Dangerfield lose all traces of meaning. Their story is utterly irreconcilable with conventional amatory plots and the seeming opposite of amatory fiction, the medical and social discourses that assign value to bodies. Belvideera finally takes on the status of, simultaneously, the most and least disposable character in the text. She remains, but her voice is finally deferred onto someone outside the spectrum of disability: Behn's narrator.

The narrator renders defective bodies accessible through texts, whereas the text shows the failure of all attempts to make language, power, and sexuality accessible to Maria and Belvideera. Ballaster identifies Behn's narrative voice in this text as a offering a "negotiation between masculine and feminine positions" (90), and in the conclusion of The Dumb Virgin, Behn shows that all amatory bodies are accessible to us as $21^{\text {st }}$ century readers if we learn how to read the signs configuring them.

Finally, Belvideera, Maria, and Dangerfield each take on positions of alterity and abjection in relation to Behn's narrator, and the text shows that characters without access to language can become victims of or at the very least the targets of language when they enter into the discourses that encircle and encode them. Textual and sexual accessibility in The Dumb Virgin lead to the characters' marginalization. Each becomes a victim; each transforms from a speaking individual with autonomous desires into a sign of Behn's authorship. What she achieves, then, is the creation of a closed system from openly accessible signs. She encircles them with her conventions and her literary reputation, and she ensures that bodies are not subordinated to the limits of either medical knowledge or amatory discourses. 
By telling the story of a mute woman who becomes a victim of rape, Behn allegorically works through the stereotypical ways in which Restoration medical culture marginalized all female bodies and viewed not only disabled women's bodies but all women's bodies as disposable. She also systematically demonstrates the linkages between sexual power and the inscriptive value of women's bodies.

For feminist scholars, The Dumb Virgin provides a critical lens for thinking about the ways in which we continue to devalue and disregard many manifestations of sexuality. When we consider the ways in which The Dumb Virgin upholds a system in which the value assigned to bodies leads to different degrees of sexual and textual exploitation, we become more aware of and committed to rehabilitating the bodies of differently-abled characters in the text. We also acquire new ways of looking at bodies that exist off the grid of cultural normalcy without reintroducing the dialectic of monstrosity as acceptable or natural.

As feminist theorist Rosemarie Garland-Thomson has explained, "Feminist disability studies questions the dominant premises that cast disability as a bodily problem to be addressed by normalization procedures rather than as a socially constructed identity and a representational system similar to gender” (1559). Behn's narrative prompts us to rethink the ways in which disability and femininity were both imagined as problems during the seventeenth century, when in fact both of these markers of identity were being created in order to instate patriarchal values as not only natural but necessary.

The defective female bodies and indeed the socially-created version of the female body as inherently defective play a thematic role in Behn's The Dumb Virgin, but as we gain access to Belvideera and Maria's bodies in their literary forms, we need to refuse to simply continue the process of marginalization and spectacle-making; we must open the canon to be more inclusive and bring our scholarship to bear on enduring feminist issues about the abuse of power against disabled people. According to data collected in 1990, as many as $83 \%$ of developmentally disabled females and 32\% of developmentally disabled males are victims of sexual assault (Stimpson and Best). SASPs recognize that disabled individuals face increased risks because of their reliance on and compliance to caregivers; their need for bodily assistance; their isolation from "normal” peers; physical, visual, or auditory disabilities that hinder self protection; language or speech barriers that may impede telling a perpetrator to stop or reporting an assault; impaired cognitive abilities; limited prevention education; and stereotypes surrounding the relationship between disabled bodies and social standards of sexuality.

Behn did not write The Dumb Virgin to expose such statistics, but she does document a gap between the values of amatory fiction and the reality of the bodies that populate them. She shows that rape is a form of exploitive power exerted when femininity is embodied in or as a vulnerable form, and she shows that, in the context of Restoration cultural and medical values, all female bodies have the potential to be read as abnormal. Behn gives us access to conversations about sexuality and disability in our classrooms and in our scholarship that can and should touch on the ways in which changes in access do not easily or always produce power dynamics that are reconcilable to our values. 


\section{Notes}

1. Behn's representations of female sexual agency, and her depictions of the complex interactions between gender and power in rape scenes, are not exclusive to her prose fiction. The attempted rape of Florinda in The Rover (1677) has received a tremendous amount of scholarly attention. Behn's lack of moral outrage frequently captures the attention of her modern-day readers, as does her explicit reinforcement of the distinction between women who deserve to be victims of sexual force and women who do not. As Susan J. Owen has noted, "No moral is drawn, and the implication seems to be that if the woman concerned had not been Florinda, the gang-rape could have gone ahead" (132). Behn singles out Florinda as a virtuous woman who should not be raped, and she uses the containing or regulatory structure of the comic form to ensure that Florinda cannot be raped. She embodies the "two principal patriarchal definitions of women [ladies and whores]" that Behn blurs in many of her works (Pacheco 323). Other rape scenes in Behn's works unsettle any binary opposition between virgin and whore by dismantling categories of gender, class, race, sexuality, disability, and other features of embodiment. A Paraphrase on Oenone to Paris (1680) includes what modern readers might view as victim blaming: "still the Rape hides the Adult'rous Deed" (259). For the purposes of this study, though, I am focusing exclusively on Behn's narrative prose because her narrator's voice very frequently allows for the creation of dialogic conceptions of consent or sexual agency, as in The Dumb Virgin or in the final scene of The Fair Jilt, in which Miranda's sexuality becomes something that the narrator accommodates.

2. Kudlick refers specifically to John Knox's 1558 pamphlet "First Blast of the Trumpet against the Monstrous Regiment of Women.” Similar strategies, though, could be isolated in Restoration and eighteenth-century texts including John Wilmot, Earl of Rochester's “The Disabled Debauchee” (1680), Jonathan Swift's The Battle of the Books (1704), or even Behn's own The Second Part of the Rover (1681). While such thinking is no longer the norm, one needs not look too far to see that stereotypes linking female sexual behavior to disability continue to circulate. On 2 February 2012, Virginia State Delegate Bob Marshall stated: "The number of children who are born subsequent to a first abortion with handicaps has increased dramatically. Why? Because when you abort the first born of any, nature takes its vengeance on the subsequent children.” Marshall seems to imagine women's reproductive choices as having an almost mythical power over their children's bodies; at the same time, he renders disabled children as anomalous and without value beyond their ability to serve as a punishment to a mother.

3. See for example Bacon "Of Deformity” and Montaigne’s "Of the Affection of Fathers to Their Children” and "Of Presumption” for representative examples. Lennard J. Davis offers an overview of the early modern intellectual traditions that attempted to explain the relationship between external defects and internal qualities before turning to his own analysis of Samuel Johnson's “multiple disabilities,” which Davis views as being socially reassigned as oddities by Johnson’s contemporaries because of his brilliance.

4. Cockayne uses the term "prelingually deaf" to describe individuals born with a congenital disability making them deaf and rendering them mute because they have never heard 
language. Behn seems to create Maria as mute rather than deaf and mute, but she does not provide a clear medical rationale for her condition. In some ways, this makes the text take on an even stronger allegorical tone. Maria literally cannot speak because of her mother and acquires language when her brother rapes her. 
Works Cited

Ballaster, Ros. Seductive Forms: Women's Amatory Fiction from 1684 to 1740. Oxford: Clarendon, 1992. Print.

Behn, Aphra. "The Dumb Virgin: Or, The Force of Imagination.” The Works of Aphra Behn. Volume 3. Edited by Janet Todd. London: Pickering, 1995. 335-60. Print.

---. The Fair Jilt. Todd Volume 3. 1-49.

---. The Lucky Mistake. Todd Volume 3. 162-204.

---. Oroonoko. Todd Volume 3. 50-119.

---. “The Unfortunate Bride: Or, The Blind Lady a Beauty.” Todd Volume 3. 321-34.

Bordo, Susan. "The Body and the Reproduction of Femininity.” Conboy, Medina, and Stanbury 90-112.

Braidotti, Rosi. “Mothers, Monsters, and Machines.” Conboy, Medina, and Stanbury 59-79.

Cockayne, Emily. "Experiences of the Deaf in Early Modern England.” The Historical Journal 46.3 (Sept. 2003): 493-510. Print. http://dx.doi.org/10.1017/S0018246X03003121

Conboy, Katie, Nadia Medina, and Sarah Stanbury. Writing on the Body: Female Embodiment and Feminist Theory. New York: Columbia UP, 1997. Print.

Davis, Lennard J. "Dr. Johnson, Amelia, and the Discourse of Disability in the Eighteenth Century." "Defects": Engendering the Modern Body. Eds. Helen Deutsch and Felicity Nussbaum. Ann Arbor: U of Michigan P, 2000. 54-74. Print.

Garland-Thomson, Rosemarie. "Feminist Disability Studies.” Signs 30.2 (Winter 2005): 155787. Print. http://dx.doi.org/10.1086/423352

Gowing, Laura. Common Bodies: Women, Touch and Power in Seventeenth-Century England. New Haven: Yale UP, 2003. Print.

Hay, William. Deformity: An Essay. $4^{\text {th }}$ Edition. London, 1754. Eighteenth Century Collections Online. Web. 10 Jan. 2012.

Hobgood, Allison P., and David Houston Wood. "Introduction, Disabled Shakespeares.” Disability Studies Quarterly 29.4 N.p. 2009.Web. 15 Sept. 2011. http://dsqsds.org/issue/view/42.

Kudlick, Catherine J. “Disability History, Power, and Rethinking the Other.” PMLA 120.2 (Mar. 2005): 557-61. Print. 
Mintz, Susanna B. “Freak Space: Aphra Behn’s Strange Bodies.” Restoration 30 (Fall 2006): 119. Print.

Montopoli, Brian. "Va. Lawmaker: Disabled Kids are God's Punishment for Abortion.” N.p. 2012. Web. 22 Feb. 2012. http://www.cbsnews.com/8301-503544_162-6232759503544.html.

Moser, Ingunn. "Sociotechnical Practices and Difference: On the Interferences between Disability, Gender, and Class.” Science, Technology, and Human Values 31.5 (Sept. 2006): 537-64. Print. http://dx.doi.org/10.1177/0162243906289611

Nussbaum, Felicity. The Limits of the Human: Fictions of Anomaly, Race, and Gender in the Long Eighteenth Century. New York: Cambridge UP, 2003. Print.

Owen, Susan J. "Drink, Sex, and Power in Restoration Comedy.” A Pleasing Sinne: Drink and Conviviality in Seventeenth-Century England. Ed. Adam Smyth. Cambridge: Brewer, 2004. 127-42. Print.

Pacheco, Anita. "Rape and the Female Subject in Aphra Behn’s The Rover.” ELH 65.2 (1998): 323-45. Print. http://dx.doi.org/10.1353/elh.1998.0013

Salmon, William. Aristotle's Master-Piece Compleated. London, 1702. Eighteenth-Century Collections Online. Web. 10 Jan. 2012.

Sharp, Jane. The Midwives Book. London, 1671. Brown University Library. Web. 3 Dec. 2011.

Stimpson, L. and MC Best. “Courage above All.” Sexual Assault against Women with Disabilities. Toronto: Disabled Women’s Network, 1991. Print.

Todd, Janet, ed. The Works of Aphra Behn. 3 vols. London: Pickering, 1992-1995. Print. 